\title{
Phytobiotic effect of Marrubium vulgare and Leonurus sibiricus on productive performance of griller-type broilers
}

\section{Valfredo Schlemper ${ }^{1,2^{*}(i)}$ Wellinton Thiago Molinetti ${ }^{1,2}$ (iD) Diogo Gasparin Prando ${ }^{1}$ (D) Jucieli Weber ${ }^{3}$ (D) Susana Regina de Mello Schlemper ${ }^{1}$ D}

${ }^{1}$ Curso de Medicina Veterinária, Universidade Federal da Fronteira Sul (UFFS), 85770-000, Realeza, PR, Brasil. E-mail: valfredo.schlemper@uffs.edu.br. *Corresponding author.

${ }^{2}$ Programa de Pós- graduação em Saúde, Bem-Estar e Produção Animal Sustentável na Fronteira Sul, Universidade Federal da Fronteira Sul (UFFS), Realeza, PR, Brasil.

${ }^{3}$ Curso de Nutrição, Universidade Federal da Fronteira Sul (UFFS), Realeza, PR, Brasil.

ABSTRACT: The food industry is in a continuous search for strategies of reducing of antibiotic residues in livestock production, given the development of antibiotic-resistant bacteria. In that context, there is a consistent increasing in the usage of alternative feed phytogenic additives. Due to the pharmacological, the plants Marrubium vulgare and Leonurus sibiricus, are both potential replacements for growthpromoting antibiotics. This study evaluated the productive performance and analyze the sensory qualities in the meat of broiler that were administered M. vulgare and L. sibiricus infusions. A total of 320 chicks from an poultry farm were distributed in 8 groups groups according treatments by 28 days: Control Group (Saline); Positive control (tylosin 1\%, 50 ppm); Groups of M. vulgare (MV) infusion: 2\% (MV2), 4\% (MV4) and 6\% (MV6); and groups treated with L. sibiricus (LS) infusion: 2\% (LS2), 4\% (LS4) and 6\% (LS6), all of them received relative doses corresponding to the live weight percentage in milliliter. There was weght gain in MV6 and LS6 group and a better food conversion in MV4, MV6, LS4, and LS6. In addition, weight gain and enhancement of the pectoral muscles were observed in these groups. The sensory analysis revealed that the broilers' meat of MV had a more intense flavor. For marketing purposes the meat from birds that received LS had a better demand. Improvement of productive performance and sensory qualities of the broilers meat might be associated with the phytobiotic activity in it. Therefore, $M V$ and LS can be used as natural growth promoter in broilers.

Key words: antibiotic, growth promoters, meat sensory qualities, phytogenic additive, poultry.

Efeito fitobiótico da Marrubium vulgare e Leonurus sibiricus sobre o desempenho produtivo de frangos de corte tipo griller

RESUMO: A indústria de alimentos busca a redução de resíduos de antibióticos na criação intensiva de animais de produção devido ao desenvolvimento de bactérias resistentes. Nesse contexto, tem havido um aumento no uso de aditivos fitogênicos alternativos nas rações. Devido às suas propriedades farmacológicas demonstradas anteriormente as plantas Marrubium vulgare e Leonurus sibiricus tem potencial como aditivos em substituição aos antibióticos promotores de crescimento. O objetivo desse estudo foi avaliar o desempenho produtivo e analisar as qualidades sensoriais da carne de frangos que receberam a administração da infusão da M. vulgare (MV) e da L. sibiricus (LS). 320 pintainhas de um criatório industrial foram distribuidas em oito grupos experimentais: Grupo Controle (Salina); Controle Positivo (tilosina 1\%, 50 ppm); Grupos tratados com MV: 2\% (MV2), 4\% (MV4) e 6\% (MV6); e grupos tratados com a LS: 2\% (LS2), 4\% (LS4) e 6\% (LS6), e todos eles receberam doses relativas correspondendo à percentagem de peso vivo, em mililitros. Houve maior ganho de peso no $28^{\circ}$ dia nos grupos MV6 e LS6 e melhor conversão alimentar em MV4, MV6, LS4 e LS6. Além disso, foi observado aumento no peso e circunferência dos músculos peitorais nesses grupos. A análise sensorial revelou que amostras de carne do grupo MV tiveram sabor mais intenso do que no grupo controle. Na intenção de compra, a carne dos animais que receberam LS teve maior preferência. A melhoria do desempenho produtivo e das características sensoriais da carne de frangos pode estar associada à atividade fitobiótica. Assim, MV e LS podem ser usados como promotores de crescimento naturais para frangos de corte.

Palavras-chave: antibióticos, promotores de crescimento, qualidades sensoriais, aditivos fitogênicos, frangos.

\section{INTRODUCTION}

Antimicrobial agents are essential tools for the control of bacterial infections. In under-doses, they act in improving zootechnical performance of livestock production, practice that contributes to the development of antibioticresistant bacteria (BARTON, 1998). In this context, there is an increasing concern regarding the use of natural feed additives including phytobiotic or phytogenic, as alternatives to antibiotics in animal feed (WENK, 2003; BONATO et al., 2008). 
Phytobiotics are natural bioactive compounds from the secondary metabolism of plants, which can be administered to improve zootechnical development (HASHEMI \& DAVOODI, 2010; WALLACE et al., 2010).

Secondary metabolites such as tannins, steroids, phenols, flavonoids, terpenes and saponins (LIMA et al., 2006) are phytochemical agents involved in biologic and therapeutic activities of plants in animals (HASHEMI \& DAVOODI, 2010). Generally, phytobiotic formulations derived from botanic material have a synergic effect when natural chemical compounds are associated in the whole plant (TOGHYANI et al., 2010). Several phytochemical products from plants are being considered as growth promoters and, according to research, they can increase the income obtained from industrial poultry (WALLACE et al., 2010; LANDY et al., 2011).

$M$. vulgare (Lamiaceae), popularly known as "maromba" or "horehound", is a perennial and shrubby plant introduced by European immigrants and adapted in Southern Brazil. Traditionally, the infusion or decoction of its flowering aerial parts is used in folk medicine for the treatment of respiratory and gastrointestinal diseases (SCHLEMPER et al., 1996). Its pharmacologic effect was first described by SCHLEMPER et al. (1996) following the ethnoindication as digestive and antispasmodic agent made with $M$. vulgare hydro-alcoholic extract in several smooth muscle preparations in vitro, which inhibit the contractile action of neurotransmitters. Also, studies were performed using $M$. vulgare extract, which demonstrated a gastro-protective activity (OLIVEIRA et al., 2011). In addition, its multifunctionality was confirmed through hypoglycemic (VILLANUEVA et al., 2017), vasorelaxant (ELBARDAI et al., 2004), analgesic (MEYRE-SILVA et al., 2005), anti-inflammatory (EL ABBOUYI et al., 2013), antioxidant (WEEL et al., 1999) and antimicrobial (ZARAI et al., 2011) effect.

L. sibiricus (Lamiaceae), popularly called "erva de santo filho" or "rubim" is used for the treatment of cold, bronchitis, rheumatism, bleeding, edema, abscesses, and kidney problems (BOWN, 2002). It is widely used as an anti-inflammatory agent and its activity on cytokine liberation from mast cells was evaluated by SHIN et al., (2009). Extracts from $L$ sibiricus showed high antioxidant properties on DNA damage induced by oxidative stress in Chinese hamsters" ovarian cells. The phenolic acids and flavonoids present in the extract may be responsible for the protective action on DNA (SITAREK et al., 2016).
Pharmacologic actions from both plants were validated scientifically, and could be attributed to the phytobiotic action on poultry as an antiinflammatory (SHIN et al., 2009; OLIVEIRA et al., 2017), antioxidant (WEEL et al., 1999; KADRI et al., 2011) and antimicrobial (MASOODI et al., 2008; SITAREK et al., 2017) agent. Only experimental models such as rodents and guinea pigs, have been administered $M$. vulgare and L. sibiricus, however the possible growth promoter effects in livestock production have not been investigated.

Therefore, this study investigated the phytobiotic effects of $M$. vulgare and L. sibiricus, via the zootechnical performance and sensory analysis of the meat of broilers, after continuous MV and LS infusions administration.

\section{MATERIALS AND METHODS}

\section{Plants material}

Botanical material of $M$. vulgare was collected in a private plantation in Bom Retiro, Santa Catarina, and L. sibiricus cultivated lands in Ampére, Paraná, between September 2016 and February 2017. $M$. vulgare botanical identification was performed by Dr. Leila da Graça Amaral from the Botanical Department of Federal University of Santa Catarina - UFSC, Florianópolis, SC, and an exsiccate was stored in the herbarium under the number 26699. $L$. sibiricus was identified by Dr. Lívia Temponi from UNOP Herbarium of Universidade Estadual do Oeste do Paraná (UNIOESTE), Campus Cascavel, PR, and its exsiccate was stored under the number UNOP 1012.1 by Rauber, R. C.

\section{Infusions preparation and thin layer cromatography} analysis

Aerial parts from $M$. vulgare and $L$. sibiricus were crushed in $2 \mathrm{~cm}$ particles in order to release the active compounds in infusion water. For the sake of obtaining the infusion, $50 \mathrm{~g}$ of the plants was added in $500 \mathrm{ml}$ of water at $100{ }^{\circ} \mathrm{C}$ during 15 minutes, and after it was submitted to filtration with gauze, was diluted in phosphate buffered solution to a desired concentration.

A qualitative chromatographic profile of the infusions was evaluated by thin layer chromatography (TLC) using aluminium plates coated with silica gel $\left(\right.$ Merck $\left.^{\circledR}\right)$, thickness $200 \mathrm{~mm}$, with several solvent systems. Spots were visualized by spraying specific reagents such as anisaldehyde-sulfuric acid (terpenes and steroids), iron chloride (flavonoids) and Dragendorff (alkaloids), and the general reagents were 
ultra-violet irradiation and sulfuric acid-methanol (MARINI-BETTÒLO et al., 1981),

\section{Trial design and broiler's management}

This study was performed in an industrial poultry farm under controlled temperature conditions, with a photo-period $1 / 23 \mathrm{~h}$, water and growth feed given ad libitum. A total of 320 newborn female chicks (Halal certification) of COBB pedigree (1-day-old and weight of 49 grams) were used for this study. Drug administration was done orally using gavage from the $1^{\text {st }}$ to $28^{\text {th }}$ days of the trial protocol. Animals were divided into eight groups of 10 animals each and the experiments were done in quadruplicate, per animal per group, thus amounting $\mathrm{N}$ of 40 animals per group at end of the trial protocol. Groups treated with $M$. vulgare (MV) infusion: 2\% (MV2), 4\% (MV4) and 6\% (MV6); and groups treated with $L$. sibiricus (LS) infusion: $2 \%$ (LS2), 4\% (LS4) and 6\% (LS6), all received relative doses (in milliliter) corresponding to their live weight percentage. $\mathrm{NC}$ received water, and $\mathrm{PC}$ received growth promoter antibiotic for poultry (tylosin $1 \%$ ), at a dosage of 50 parts per million (ppm) (BERRANG et al., 2007).

\section{Average weight}

At end of the experiment (28 days), in order to calculate the final average weight, all the animals were weighted according to their respective groups, with 5 animals removed of each repetition. A total of 20 animals were included for treatment according to the average weight of each group.

\section{Feed conversion}

In order to analyze feed conversion, the total feed intake and total poultry weight, was recorded and dead birds and leftover food were deducted at the end of the experiment.

\section{Development of inner organs and pectoral muscle \\ Poultries were identified and weighed} individually, and in the sequence they were slaughtered, after being stunned and unconsciousness in the $\mathrm{CO}_{2}$ euthanasia chamber. They were exsanguinated and eviscerated manually, with separation and weighing of their liver, proventriculus, and gut (from duodenum to cloaca). In addition, the pectoral muscle was removed manually, in order to analyze its weight and circumference. The relative weight (in percentage) of the viscera was obtained in relation to the overall weight of the birds.

\section{Sensory and color analysis of the meat Color analysis}

After being defrosted, meat samples were immediately submitted to color quantification using a
Minolta CR-300 colorimeter (Mahwah/ NJ, USA) that is previously calibrated in white surface according to predefined standards (BIBLE \& SINGHA, 1993) and CieLab system for determining samples color. Meat was cut in a flat surface and color measurement was directly performed. In the Hunter color system corrected by CieLab, $L^{*}$ values match the luminosity and range from 0 (black) and 100 (white), and values of coordinates $\mathrm{a}^{*}$ and $b^{*}$ range from $-a^{*}$ (green) to $+a^{*}$ (red) in a scale of 0 to 60 scale and $-b^{*}$ (blue) to $+b^{*}$ (yellow) as well in a scale of 0 to 60 (HARDER et al., 2007).

\section{Sensory analysis}

Sensory analysis was performed in the Laboratory of Food Tecnology and Sensory Analysis at the Federal University of Fronteira Sul - UFFS, located in Realeza - PR. The meat of the birds was treated with higuer doses of the plants (MV6 and LS6), and comparison was done among them and with the control group. A total of 61 meat tasters were recruited at randomly, without gender or social class restriction. They were accommodated in individual cabins under fluorescent lighting. Samples were assessed on taste acceptability, with pleasurable scales of nine points ( $9=$ liked a lot; $5=$ not liked or disliked; and $1=$ disliked a lot). The tasters was asked to give a description the meat they liked or not liked in each sample based on their respective taste perception. The tasters were requested to rate their purchase intention on a 5 points scale $(5=\mathrm{I}$ really do, $3=$ Maybe yes, maybe not; $1=$ No, I wouldn't). In addition, through multiple comparison tests or control difference tests, the significant difference among two treatments (samples) and control (reference) was verified.

Carcass cuts (breast, drumstick and thigh) were performed, identified and kept in the freezer at $-18{ }^{\circ} \mathrm{C}$ until analysis. On the day of the sensory analysis, meat cuts were kept under refrigeration (5 ${ }^{\circ} \mathrm{C}$ ) for 24 hours defrosting. Cuts were divided in three equal pieces and put in three stainless steel pans with 4 liters of water each and $3 \%$ of table salt in relation to the meat weight. Meat was cooked for an hour. After cooling, the meat was shredded manually and put into plastic cups for the sensory test. Samples were served in $50 \mathrm{ml}$ white plastic cups codified with three-digit random numbers, and a fork. Mineral water was offered before and during the tasting in order to clean the tasters' palate.

\section{Statistical assessment}

Data was organized as arithmetic average $(\bar{X})$ more or less the standard error of the means submitted to one-way or two-ways variance 
analysis (ANOVA) and confirmed by Tukey test for zootechnical data and t-test and one-way ANOVA for sensory data. Comparisons among NC, PC, and groups treated with plants on zootechnical and sensory parameters were done using Graphpad Prism version 7.0 for windows (GraphPad Software, San Diego, California, USA). Results were considered statistically significant at $P<0.05$.

\section{RESULTS}

Phytochemical screening of $M$. vulgare and $L$. sibiricus infusions

Among secondary metabolites obtained from MV andLS infusions, qualitative- phytochemical studies showed the presence of terpenoids, steroids, aglycons and total sugars through TLC. Among the latters, diterpenes, sesquiterpenes, phenols, and steroids predominate in this plants and stand out like traditional phytochemical compounds of interest in this research.

\section{Average weight}

In relation to the final average weight of the poultry shown in table 1, at the last day of the experiment, there was a significant difference in MV6 and LS6 group when compared with $\mathrm{NC}$ and a significant decrease in average weight for $\mathrm{PC}(P<0.05)$.

\section{Feed Conversion}

In the table 1 the feed conversion results reveal that all groups that received plants infusion showed a feed intake reduction to produce the same kilogram live weight; however, in the statistical test it is possible to observe a significant reduction for the groups MV4, MV6, LS4, and LS6, as well as feed conversion increment for PC when compared to $\mathrm{NC}$ $(P<0.05)$. In this case, the growth promoter antibiotic showed no improving effects on the feed conversion.

\section{Development of inner organs and pectoral muscles}

There was no significant difference based on statistical analysis of inner organs development when compared to the relative weight of liver, intestine and proventriculus of each animal among groups (Table 2). When analyzing the pectoral muscle relative weight, it was observed that there was a significant difference $(P<0.05)$ in all groups treated with plants infusion in relation to NC. In a statistical test for pectoral muscle circumference, a significant difference in MV4, MV6, LS4 and LS6 was confirmed $(P<0.05)$ (Table 2). During necropsy, no pathological changes of the organs were macroscopically identifiable.

\section{Sensory and color analysis}

In relation to sensory analysis, LS6 and Control groups showed equal averages (4.80 and

Table 1 - Effect of Marrubium vulgare and Leonurus sibiricus infusions on the relative weight, daily gain, feed intake and feed convertion of the griller-type broilers.

\begin{tabular}{lccc}
\hline Groups & Final body weight $(\mathrm{g})$ & Average Daily gain $(\mathrm{g})$ & Feed Convertion Ratiob(g) \\
\hline NC & $1155 \pm 11.12$ & $39.50 \pm 0.53$ & $1390 \pm 0.01$ \\
PC & $1033 \pm 35.52^{\mathrm{a}}$ & $35.14 \pm 1.58$ & $1500 \pm 0.03^{\mathrm{b}}$ \\
MV 2\% & $1102 \pm 33.92$ & $37.61 \pm 1.72$ & $1370 \pm 0.04$ \\
MV 4\% & $1210 \pm 44.80$ & $39.71 \pm 2.22$ & $1310 \pm 0.02^{P<0.05}$ \\
MV 6\% & $1245 \pm 27.28^{P<0.05}$ & $42.71 \pm 1.21^{P<0.05}$ & $1228 \pm 0.03^{P<0.01}$ \\
LS 2\% & $1113 \pm 36.32^{2}$ & $38.00 \pm 1.83$ & $1366 \pm 0.03$ \\
LS 4\% & $1203 \pm 40.96$ & $41.21 \pm 1.81$ & $1306 \pm 0.02^{P<0.05}$ \\
LS 6\% & $1283 \pm 39.61^{P<0.05}$ & $44.07 \pm 1.85^{P<0.01}$ & $1291 \pm 0.02^{P<0.01}$ \\
\hline
\end{tabular}

The values are expressed as the mean \pm SEM of broilers. Eight birds of each treatment were used.

$P<0.05, P<0.01$ and $P<0.001$, statistically different according to Tukey's test.

$\mathrm{a}=P<0.05, \mathrm{~b}=P<0.01$ statistically significant $\mathrm{PC}$ in relation to $\mathrm{NC}$.

MV: Marrubium vulgare infusion; LS: Leonurus sibiricus infusion; NC: Negative control; PC: Positive control. 
Table 2 - Effect of Marrubium vulgare and Leonurus sibiricus infusions on the relative weight (\% relative weight) of selected organs calculated in relation to the final weight, and the pectoral circumference $(\mathrm{cm})$ of the griller-type broilers.

\begin{tabular}{lccccc}
\hline Groups & Liver \% & Breast Weight \% & Proventriculus \% & Intestine \% & Pectoral Circumference (cm) \\
\hline NC & $3.40 \pm 0.02$ & $20.43 \pm 0.07$ & $3.99 \pm 0.01$ & $4.83 \pm 0.01$ & $22.40 \pm 0.70$ \\
PC & $3.58 \pm 0.01$ & $21.43 \pm 0.22$ & $4.28 \pm 0.01$ & $4.81 \pm 0.01$ & $21.40 \pm 3.70$ \\
MV 2\% & $2.87 \pm 0.01$ & $23.34 \pm 0.08^{\mathrm{P}<0.05}$ & $3.77 \pm 0.00$ & $5.07 \pm 0.02$ & $22.90 \pm 2.20$ \\
MV 4\% & $3.21 \pm 0.00$ & $24.31 \pm 0.10^{P<0.001}$ & $3.80 \pm 0.01$ & $5.08 \pm 0.03$ & $23.90 \pm 4.70^{\mathrm{P}<0.05}$ \\
\hline MV 6\% & $3.10 \pm 0.01$ & $24.45 \pm 0.09^{P<0.001}$ & $3.51 \pm 0.01$ & $5.05 \pm 0.01$ & $24.40 \pm 0.70^{\mathrm{P}<0.001}$ \\
\hline LS 2\% & $3.02 \pm 0.00$ & $24.71 \pm 0.08^{P<0.001}$ & $3.48 \pm 0.00$ & $5.05 \pm 0.00$ & $23.80 \pm 1.80^{\mathrm{P}<0.05}$ \\
\hline LS 4\% & $2.89 \pm 0.00$ & $22.98 \pm 0.15^{\mathrm{P}<0.05}$ & $3.92 \pm 0.02$ & $4.92 \pm 0.01$ & $24.40 \pm 2.00^{\mathrm{P}<0.05}$ \\
\hline LS 6\% & $2.90 \pm 0.00$ & $24.67 \pm 0.08^{P<0.001}$ & $3.24 \pm 0.01$ & $4.67 \pm 0.00$ & $25.00 \pm 8.00^{\mathrm{P}<0.01}$ \\
\hline
\end{tabular}

The values are expressed as the mean \pm SEM of broilers. Eight birds of each treatment were used.

$P<0.05, P<0.01$ and $P<0.001$, statistically different according to Tukey's test.

MV: Marrubium vulgare infusion; LS: Leonurus sibiricus infusion; NC: Negative control;

PC: Positive control.

5.0 respectively), without statistical difference and similarity in taste when analyzing meat characteristics in multiple comparison tests. MV6 had a fairly more intense taste than the control group (average value $5.40),(P<0.05)$. In the pleasurable scale, there was no significant difference between the plants in relation to taste, but there was a non-significant tendency to prefer LS to MV, thus showing punctuation averages among tasters as "I liked gently" (7.0) and "regularly" (6.6) (Figure 1).

When asked about purchase intention, poultry which received LS6 infusion differed statistically $(P<0.05)$ in relation to the meat with MV6 infusion administration, and the purchase intention average reached between "I would buy always" and "I would buy frequently" ( 1.70 and 2.30 , respectively) for each plant, thus agreeing with the results obtained by pleasurable scale (Figure 1). L* (luminosity), $\mathrm{a}^{*}$ (red color intensity) and $\mathrm{b}^{*}$ (yellow color intensity) characteristics did not differ statistically, but there no significant tendency of the treated groups to show more luminosity than the control group. Similarly, positive averages demonstrated a reduction in yellow color intensity (Table 3).

\section{DISCUSSION AND CONCLUSION}

The main objective of the research was to evaluate, for the first time, the improvement of productive performance and sensory quality of broilers meat after administration of $M$. vulgare and L. sibiricus infusions. Mechanisms of action by which the phytogenics act in order to get a better zootechnical development have still not been clearly elucidated (WINDISCH et al., 2008; WALLACE et al., 2010).

The main indicators for the enhancement effect on zootechnical indexes and meat taste for both plants could be related to the interaction of antimicrobial (ZARAI et al., 2011), antioxidant (WEEL et al., 1999), mucous membrane protective (OLIVEIRA et al., 2011), anti-inflammatory (EL ABBOUYI et al., 2013), and immunomodulatory activities (DAOUDI et al., 2013), which (together) could contribute to a better animal health, resulting in a controlled phytogenic effect of variables in the dark-house intensive confinement system.

It is possible to suggest that the responsible mechanisms for the phytobiotic action of the plant are somehow linked to their spasmolytic and gastroprotective effects (SCHLEMPER et al., 1996; OLIVEIRA et al., 2011). Their spasmolytic effect could contribute the delay of gut contents, thus ensuring better nutrients absorption. KHADEM et al. (2014) suggested that the main mechanism of action linked to growth promoters are connected to the anti-inflammatory effect of antibiotics and phytogenic compounds, since sub-doses usually used did not reach a minimum inhibitory concentration (MIC) that is able to eliminate pathogenic bacteria from the gastrointestinal tract. The anti-inflammatory and non-antibiotic hypothesis of antimicrobial 


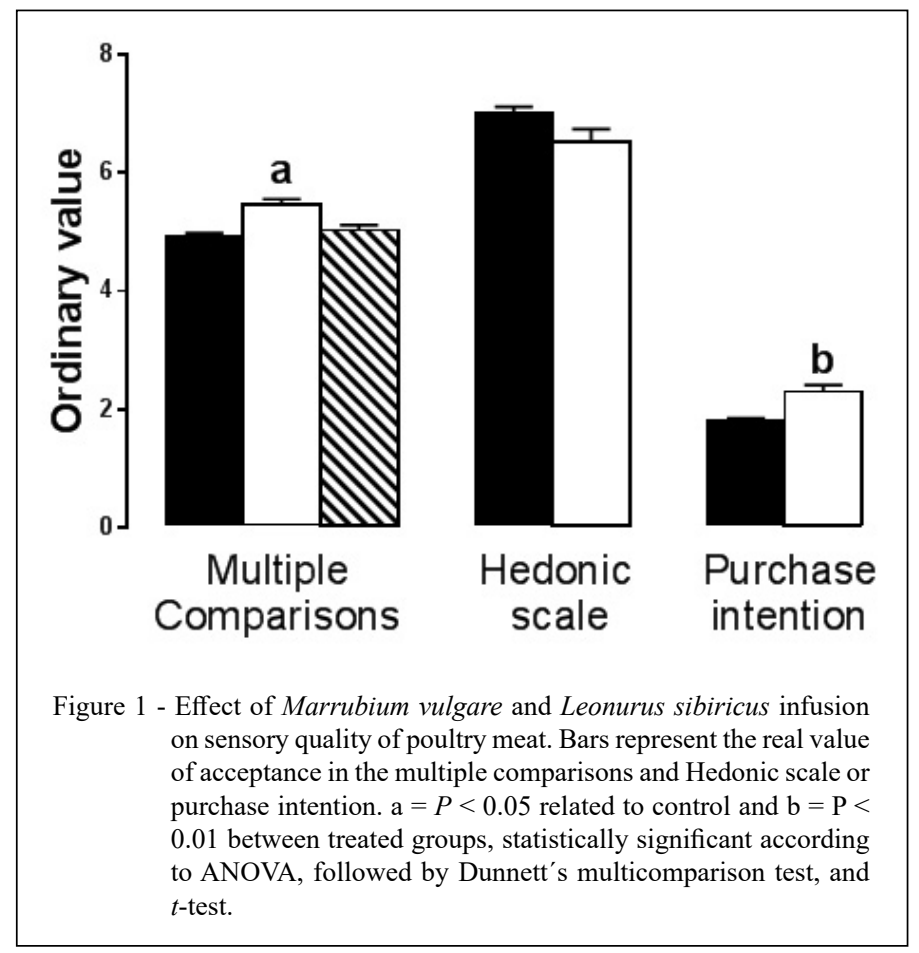

growth promoters are based on in vitro tests with oxytetracycline and Macleaya cordata extract which demonstrated an anti-inflammatory effect using half of MIC recommended for antibiotic action of each drug. In the in vivo tests with broilers, M. cordata showed a significant reduction in inflammatory gene expression in the jejunum, thus supporting the antiinflammatory theory.

M. vulgare e L. sibiricus present antiinflammatory and antioxidant properties which may be related to the mechanism of zootechnical performance on broilers (WEEL et al., 1999; SHIN et al., 2009; OLIVEIRA et al., 2017). Recently, wide and careful in vitro pharmacological approaches have corroborated the possibility that oxidative metabolism suppression or delay could explain some phytobiotic action of plants when administered in vivo (SITAREK et al., 2016; OLIVEIRA et al., 2017). LEE et al. (2018) evaluated antioxidant activity in broilers after adding Allium hookeri to the feed by monitoring specific enzymes of oxidative metabolism thus obtaining important results on growth promotion

Table 3 - Effect of the administration of Marrubium vulgare and Leonurus sibiricus infusion on the color of the meat produced in broilers.

\begin{tabular}{lccc}
\hline Groups & $\mathrm{L}^{*}$ & $\mathrm{a}^{*}$ & $\mathrm{~b}^{*}$ \\
\hline NC & $33.39 \pm 1.76$ & $3.87 \pm 0.39$ & $6.97 \pm 0.29$ \\
MV & $34.14 \pm 1.34$ & $4.16 \pm 0.20$ & $6.42 \pm 0.28$ \\
LS & $36.36 \pm 1.76$ & $3.60 \pm 0.52$ & $5.40 \pm 1.89$ \\
\hline
\end{tabular}

The values are expressed as the mean \pm S.E.M of the mean of broilers. Four birds of each treatment were used. $L^{*}$ (luminosity), a (red color intensity) and $\mathrm{b}^{*}$ (yellow color intensity).

MV: Marrubium vulgare; LS: Leonurus sibiricus; NC: Negative control.

Ciência Rural, v.51, n.12, 2021. 
and, at the same time, confirming the antioxidant action of the supplement and improving the productive zootechnical performance.

In previous results, the inclusion of oregano, cinnamon and pepper essential oils in broilers' diet promoted superior digestibility and a better feed conversion (BASMACIOĞLU MALAYOĞLU et al. (2010). WINDISCH et al. (2008) demonstrated that a large part of experimental results using phytogenic additives, reveal a reduction in feed intake with increments on weight gain and better feed conversion. According to AL-KASSIE (2008), using anise 1\% and rosemary $1 \%$ during 6 weeks of treatment, dairy weight gain and feed conversion in relation to control treatment was observed.

The addition of Schinus terebinthifolius oil (aroeira-vermelha) in broilers' diet reduced the relative gut weight when compared to feed without growth promoter and there was no interference in those treated with growth promoter (SILVA et al. (2011). Growth promoters reduce intestinal inflammation, which causes lesion and increase wall thickness. In this way, growth promoters reduce intestinal thickness (COATES et al., 1963).

In the larger part of the protocols using traditional growth promoter antibiotics, significant effects on maximum challenge conditions can be observed specially at high bacterial load (RAMOS et al., 2011). In a research conducted by AMAD et al., (2011) with the addition of phytogenic compounds in broilers' feed, the inner organs development at end of study was evaluated and significant difference was found only relative to the liver weight. The absence of inner organs weight difference in this study is in accordance with previous research studies where negative effects of phytogenic additives on relative weight of the organs could not be observed (HERNÁNDEZ et al., 2004; AMAD et al., 2011). ISABEL \& SANTOS (2009) registered an important increase on breast of broilers fed with a mixture of clove and cinnamon, thus corroborating the results of this study.

Numerous studies were conducted on the phytobiotic effects produced with the addition of essential oils and seeds to the broilers' diet. Apart from improving their growth performance (ADASZYŃSKA-SKWIRZYŃSKA \& SZCZERBIŃSKA, 2019; BARBARESTANI et al., 2020), it provided beneficial alterations on the animals' intestinal morphology and macroflora. It showed an antimicrobial activity over the intestinal pathogens (Escherichia coli, Salmonella sp, coliforms bacteria) without inhibiting the amount of lactic fermentation bacteria, which is essential for the maintenance of a healthy structure of the small intestine (MOHITI-ASLI \& GHANAATPARASTRASHTI, 2018; ADASZYŃSKA-SKWIRZYŃSKA \& SZCZERBIŃSKA, 2019) in association with histomorphological properties improvements, such as the height of the villi structures and surface area (MOHITI-ASLI \& GHANAATPARAST-RASHTI, 2018), thus granting the animals more digestibility when fed with ration, a better intake of nutrients, increasing in the antioxidant capacity, and a boost of the broiler's immunity. Together, these variables contributed directly to the growth rate performance (KUMAR et al., 2017; KHATUN et al., 2018).

Although plants have bitter taste because of terpenes (POPOOLA et al., 2013), in our study, there was no meat taste alteration when comparing the MV- or LS-treated animals to control group. A combined administration of powdered clove (Syzygium aromaticum) and agrimony (Agrimonia eupatoria) or lemon balm (Melissa officinalis) added to poultry drinking water demonstrated a fairly positive effect on meat sensory evaluation when compared to control group (MARCINČAK et al. 2011). Moreover, according to ŠPERŇÁKOVÁ et al. (2007), the addition of rosemary-based supplement promoted an improvement on the sensory quality of the meat. Studies have suggested that the addition of plants with antioxidant activity in animal feeds contributes to a better sensory characteristic of the meat (LEE et al., 2004), so thus corroborating the results on taste in this study.

In accordance with MORAES et al. (2016), the addition of canola oil did not promote luminosity intensity variation between treated broilers and control. However, there was a considerable difference on the group averages in terms of color intensity, with increase in the level of canola meal when compared to the averages in our study. Meat color varies according to maize content in the poultry diet or other ingredients containing substances called xanthophylls, which are fat soluble substances that are yellowish-orange color (SILVA et al., 2000). Therefore, all groups were fed with the same feed formulation, thus supporting our results. It was also noted that plants do not cause color pattern alteration of the meat.

The present study demonstrated that administration of $M$. vulgare and L. sibiricus infusion led to an increase in the poultry's final weight and a significant reduction of feed conversion, without alterations of sensory or meat color characteristics. This way, any gain in grams on conversion and individual weight is a large advance for industrial 
production, since it represents a reduction in the global costs of poultry farming. The mechanisms to improve broilers' productive performance still have to be investigated in the future, in order to confirm M. vulgare and L. sibiricus as potential phytobiotic agents that could be added to feeds in order to enhance zootechnical indexes and develop intensive poultry livestock.

\section{BIOETHICS AND BIOSSECURITY COMMITTEE APPROVAL}

The experimental protocol was authorized and homologated by the Ethics Committee on Animal Use of Federal University of Fronteira Sul, under numbers 23205. 003123/2016-77 for M. vulgare and 23205.005321/2016-75 for L. sibiricus, and Human Research Ethics Committee of Universidade Federal da Fronteira Sul (UFFS) under number 68761017.3.0000.5564. All procedures were performed according to the rules for animal experimentation of the E-Book regulations of Conselho Nacional de Controle da Experimentação Animal (CONCEA) (BRASIL, 2016).

\section{ACKNOWLEDGEMENTS}

We want express our gratitude to the Brazilian Foods Company, in Francisco Beltrão, Paraná, for allowing us to conduct our experiments in their griller-broiler industry. Also, we thank Valdecir Molinetti, owner of a "Dark House" poultry farm located in Ampére, Paraná, for his receptiveness in the execution of this research. W. T. M is a college student receiving a grant from PIBIC/ Fundação Araucária/UFFS (Brazil). This research did not receive any specific grant from funding agencies in the public, commercial, or non-profit sectors. The author acknowledge the financial support in part given by Coordenação de Aperfeiçoamento de Pessoal de Nível Superior (CAPES), Brasil.

\section{DECLARATION OF CONFLICT OF} INTEREST

The authors declare no conflict of interest. The founding sponsors had no role in the design of the study; in the collection, analyses, or interpretation of data; in the writing of the manuscript, and in the decision to publish the results.

\section{AUTHORS' CONTRIBUTIONS}

All authors contributed equally to the conception and design of this study, writing of the manuscript, acquisition of data or analysis and interpretation of data. All authors critically revised the manuscript and approved the final version.

\section{REFERENCES}

ADASZYŃSKA-SKWIRZYŃSKA, M.; SZCZERBIŃSKA, D. The effect of lavender (Lavandula angustifolia) essential oil as a drinking water supplement on the production performance, blood biochemical parameters, and ileal microflora in broiler chickens. Poultry Science, v.98, n.1, p.358-365, 2019. Available from:<https://reader.elsevier.com/reader/sd/pii/S00325791193
03189? token $=6$ E8220FD8D334770DB052803954D05D0C500 4BCA098927E895F9239B43459771F587137460EAF03B1E8C 5E3489695209>. Accessed: Dec. 13, 2020. doi: 10.3382/ps/pey385.

AL-KASSIE, G. A. M. The effect of anise and rosemary on broiler performance. International Journal of Poultry Science, v.7, n.3, p.243-245, 2008. Available from: <http://dx.doi.org/10.3923/ ijps.2008.243.245>. Accessed: Aug. 29, 2020. doi: 10.3923/ ijps.2008.243.245.

AMAD, A. A. et al. Effects of a phytogenic feed additive on growth performance and ileal nutrient digestibility in broiler chickens. Poultry Science, v.90, n.12, p.2811-2816, 2011. Available from: $<$ http://dx.doi.org/10.3382/ps.2011-01515>. Accessed: Aug. 29, 2020. doi: $10.3382 /$ ps.2011-01515.

BARBARESTANI, S. Y. et al. Effects of dietary lavender essential oil on growth performance, intestinal function, and antioxidant status of broiler chickens. Livestock Science, v.233, n.103958, 2020. Available from: <https://www.sciencedirect.com/science/ article/abs/pii/ S187114131931162X>. Accessed: Dec. 13, 2020. doi: 10.1016/j.livsci.2020.103958.

BARTON, M. D. Does the use of antibiotics in animals affect human health? Australian Veterinary Journal, v.76, n.3, p. 177-180, 1998. Available from: $\quad<$ http://dx.doi.org/10.1111/j.1751-0813.1998. tb10124.x>. Accessed: Aug. 29, 2020. doi: 10.1111/j.17510813.1998.tb10124.x.

BASMACIOĞLU MALAYOĞLU, H. et al. Effects of oregano essential oil with or without feed enzymes on growth performance, digestive enzyme, nutrient digestibility, lipid metabolism and immune response of broilers fed on wheat-soybean meal diets. British Poultry Science, v.51, n.1, p.67-80, 2010. Available from: $<$ http://dx.doi.org/10.1080/00071660903573702>. Accessed: Aug. 29, 2020. doi: 10.1080/00071660903573702.

BERRANG, M. E. et al. Subtherapeutic tylosin phosphate in broiler feed affects campylobacter on carcasses during processing. Poultry Science, v.86, n.6, p.1229-1233, 2007. Available from: $<$ https://doi.org/10.1093/ps/86.6.1229>. Accessed: Aug. 29, 2020. doi: $10.1093 / \mathrm{ps} / 86.6 .1229$

BIBLE, B. B.; SINGHA, S. Canopy position influences cielab coordinates of peach color. Hortscience, v.28, n.10, p.992-993, 1993. Available from: <https://journals.ashs.org/hortsci/view/ journals/hortsci/28/10/article-p992.xml>. Accessed: Aug. 29, 2020. doi: 10.21273/HORTSCI.28.10.992.

BONATO, M. A. et al. Efeito de acidificantes e extratos vegetais sobre o desempenho e qualidade de ovos de poedeiras comerciais. Ars Veterinaria, v.24, n.3, p.186-192, 2008. Available from: $<$ http://dx.doi.org/10.15361/2175-0106.2008v24n3p186-192>. Accessed: Aug. 29, 2020. doi: 10.15361/2175-0106.2008v24n 3p186-192.

BOWN, D. The Royal Horticultural Society encyclopedia of herbs \& their uses. London: Dorling Kindersley, 2002. ISBN: 0751302031.

BRASIL, Ministério da Ciência e Tecnologia. E-book normativas do CONCEA: para produção, manutenção ou utilização de animais em atividades de ensino ou pesquisa científica. 3. ed. Brasília, 2016. Available from: <https://www.mctic.gov.br/mctic/ opencms/institucional/concea/paginas/publicacoes_concea.html $>$. Accessed: Dec. 17, 2020. 
COATES, M. E. et al. A comparison of the growth of chicks in the Gustafsson germ-free apparatus and in a conventional environment, with and without dietary supplements of penicillin. British Journal of Nutrition, v.17, n.1, p.141-150, 1963. Available from: < https:// doi.org/10.1079/BJN19630015>. Accessed: Aug. 30, 2020. doi: 10.1079/ BJN19630015.

DAOUDI, A. et al. Screening of immunomodulatory activity of total and protein extracts of some moroccan medicinal plants. Toxicology and Industrial Health, v.29, n.3, p.245-253, 2013. Available from: <https://doi.org/10.1177/0748233713479898>. Accessed: Aug. 30, 2020. doi: 10.1177/0748233713479898.

EL ABBOUYI, A. et al. Anti-inflammatory effect of hydromethanolic extract from Marrubium vulgare Lamiaceae on leukocytes oxidative metabolism: an in vitro and in vivo studies. International Journal of Green Pharmacy, v.7, n.3, p.224-229, 2013. Available from: <http://dx.doi.org/10.22377/ijgp.v7i3.327>. Accessed: Aug. 30, 2020. doi: 10.22377/ ijgp.v7i3.327.

EL-BARDAI, S. et al. Comparative study of the antihypertensive activity of Marrubium vulgare and of the dihydropyridine calcium antagonist amlodipine in spontaneously hypertensive rat. Clinical and Experimental Hypertension, v.26, n.6, p.465-474, 2004. Available from: <https://doi.org/10.1081/CEH-200031818>. Accessed: Aug. 30, 2020. doi: 10.1081/CEH-200031818.

HARDER, M. N. C. et al. Quantitative evaluation by a digital colorimeter of the color of the egg of laying hens fed with annatto (Bixa orellana). Revista Portuguesa de Ciências Veterinárias, v.102, n.563-564, p.339-342, 2007. Available from: <http://www. fmv.ulisboa.pt/ spcv/PDF/pdf12_2007/339-342.pdf/>. Accessed: Aug. 30, 2020. ISSN 0035-0389.

HASHEMI, S. R.; DAVOODI, H. Phytogenics as new class of feed additive in poultry industry. Journal of Animal and Veterinary Advances, v.9, n.17, p.2295-2304, 2010. Available from: <https:// medwelljournals.com/abstract/?doi=javaa.2010.2295. 2304>. Accessed: Aug. 30, 2020. doi:10.3923/javaa.2010.2295.2304.

HERNÁNDEZ, F. et al. Influence of two plant extracts on broilers performance, digestibility, and digestive organ size. Poultry Science, v.83, n.2, p.169-174, 2004. Available from: $<$ https://doi. org/10.1093/ps/83.2.169>. Accessed: Aug. 30, 2020. doi:10.1093/ $\mathrm{ps} / 83.2 .169$.

ISABEL, B.; SANTOS, Y. Effect of dietary organic acids and essential oils on growth performance and carcass characteristics of broiler chickens. Journal of Applied Poultry Research, v. 18, n.3, p.472-476, 2009. Available from: <https://doi.org/ 10.3382/ japr.2008-00096>. Accessed: Aug. 30, 2020. doi:10.3382/japr. 2008-00096.

KADRI, A. et al. Chemical composition and antioxidant activity of Marrubium vulgare L. essential oil from Tunisia. African Journal of Biotechnology, v.10, n.19, p.3908-3914, 2011. Available from: <https://www.ajol.info/index.php/ajb/article/ view/93549\#: :text=vulgare $\% 20$ were $\% 20$ identified., and $\% 20$ germacrene $\% 20 \mathrm{D} \% 20(9.37 \% 25) . \&$ text $=$ The $\% 20$ results $\% 20$ showed $\% 20$ that $\% 20$ this, of $\% 20$ antioxidants $\% 20$ of $\% 20$ natural\%20origin>. Accessed: Aug. 30, 2020. doi:10.5897/ AJB11.301.

KHADEM, A. et al. Growth promotion in broilers by both oxytetracycline and Macleaya cordata extract is based on their anti-inflammatory properties. British Journal of Nutrition, v.112, n.7, p.1110-1118, 2014. Available from: <https://doi.org/10.1017/ S0007114514001871>. Accessed: Aug. 30, 2020. doi: 10.1017/ S00071145140018 71 .

KHATUN, J. et al. Influence of different sources of oil on performance, meat quality, gut morphology, ileal digestibility and serum lipid profile in broilers. Journal of Applied Animal Research, v.46, n.1, p.479-485, 2018. Available from: <https:// www.tandfonline.com/doi/full/10.1080/09712119.2017.1337580> Accessed: Dec. 13, 2020. doi: 10.1080/09712119.2017.1337580.

KUMAR, P. et al. Effect of black cumin seeds on growth performance, nutrient utilisation, immunity, gut health, and nitrogen excretion by broiler chickens. Journal of the Science of Food and Agriculture, v.97, n.11, p.3742-3751. Available from $<$ https://onlinelibrary.wiley.com/doi/epdf/10.1002/jsfa.8237>. Accessed: Dec. 13, 2020. doi: 10.1002/jsfa.8237.

LANDY, N. et al. The effects of Echinacea purpurea L. (purple coneflower) as an antibiotic growth promoter substitution on performance, carcass characteristics and humoral immune response in broiler chickens. Journal of Medicinal Plants Research, v.5, n.11, p.2332-2338, 2011. Available from: <http://www.academic journals.org/JMPR>. Accessed: Aug. 30, 2020. doi: 10.5897/JMPR.

LEE, J. et al. Reactive oxygen species, aging, and antioxidative nutraceuticals. Comprehensive Reviews in Food Science and Food Safety, v.3, p.21-33, 2004. Available from: <https://doi. org/10.1111/j.1541-4337.2004.tb00058.x>. Accessed: Aug. 30, 2020. doi: $10.1111 /$ j.1541-4337.2004.tb00058.x.

LEE, Y. et al. Effects of dietary Allium hookeri root on growth performance and antioxidant activity in young broiler chickens. Research in Veterinary Science, v.118, p.345-350, 2018. Available from: <https://doi.org/10.1016/j.rvsc.2018.03.007>. Accessed: Aug. 30, 2020. doi: 10.1016/j.rvsc. 2018.03.007.

LIMA, M. R. et al. The antibiotic activity of some brazilian medicinal plants. Revista Brasileira de Farmacognosia, v.16, n.3, p.300-306, 2006. Available from: <http://dx.doi.org/10.1590/ S0102-695X2006000300004>. Accessed: Aug. 30, 2020. doi: 10.1590/S0102-695X2006000300004.

MARCINČÁK, S. et al. Effect of supplementation of phytogenic feed additives on performance parameters and meat quality of broiler chickens. Slovenian Veterinary Research, v.48, n.1, p.2734, 2011. Available from: <https://www.slovetres.si/index. php/ SVR/issue/viewIssue/18/15>. Accessed: Aug. 31, 2020. UDC 636.5.083:636.087.7: 637.51.

MARINI-BETTÒLO, G. B. et al. Plant screening by chemical and chromatographic procedures under field conditions. Journal of Chromatography A, v.213, v.1, p.13-127. Available from: <https://doi.org/10.1016/S0021-9673(00)80639-1>. Accessed: Aug. 31, 2020. doi: 10.1016/S0021-9673(00)80639-1.

MASOODI, M. H. et al. Antibacterial activity of whole plant extract of Marrubium vulgare. African Journal of Biotechnology, v.7, n.2, p.086-087, 2008. Available from: <http://www.academicjournals. org/AJB > . Accessed: Aug. 31, 2020. ISSN 1684-5315.

MEYRE-SILVA, C. et al. Analgesic potential of marrubiin derivatives, a bioactive diterpene present in Marrubium vulgare (Lamiaceae). Il Farmaco, v.60, n.4, p.321-326, 2005. Available from: <https://doi.org/10.1016/j.farmac.2005.01.003>. Accessed: Aug. 31, 2020. doi: 10.1016/j.farmac.2005. 01.003. 
MOHITI-ASLI, M.; GHANAATPARAST-RASHTI, M. Comparing the effects of a combined phytogenic feed additive with an individual essential oil of oregano on intestinal morphology and microflora in broilers, Journal of Applied Animal Research, v.46, n.1, p.184-189, 2018. Available from: <https://doi.org/10. 1080/09712119.2017.1284074>. Accessed: Dec. 13, 2020. doi: 10.1080/09712119.2017.1284074.

MORAES, P. D. O. et al. Carcass yield, sensory analysis and meat quality of broilers fed canola meal. Acta Scientiarum Animal Science, v.38, n.3, p.267-274, 2016. Available from: $<$ https://doi. org/10.4025/actascianimsci.v38i3.31247>. Accessed: Aug. 31, 2020. doi: $10.4025 /$ actascianimsci.v38i3.31247.

OLIVEIRA, A. P. et al. Gastroprotective activity of methanol extract and marrubiin obtained from leaves of Marrubium vulgare L. (Lamiaceae). Journal of Pharmacy and Pharmacology, v.63, n.9, p.1230-1237, 2011. Available from: <https://doi.org/10.11 11/j.2042-7158.2011.01321. $\mathrm{x}>$. Accessed: Aug. 31, 2020. doi: 10.1111/j.2042-7158.2011.01321.x.

OLIVEIRA, A. S. et al. The ethanol extract of Leonurus sibiricus $\mathrm{L}$. induces antioxidant, antinociceptive and topical anti-Inflammatory effects. Journal of Ethnopharmacology, v.206, p.144-151, 2017. Available from: <https://doi.org/ 10.1016/j.jep.2017.05.029>. Accessed: Aug. 31, 2020. doi: 10.1016/j.jep.2017.05.029.

POPOOLA, O. K. et al. Marrubiin. Molecules, v.18, n. 8 , p.9049-9060, 2013. Available from: <https://doi.org/10.3390/ molecules18089049>. Accessed: Aug. 31, 2020. doi: 10.3390/ molecules18089049.

RAMOS, L. S. N. et al. Desempenho e histomorfometria intestinal de frangos de corte de 1 a 21 dias de idade recebendo melhoradores de crescimento. Revista Brasileira de Zootecnia, v.40, n.8, p.1738-1744, 2011. Available from: <https://doi.org/ 10.1590/ S1516-35982011000800017. Accessed: Aug. 31, 2020. doi: 10.1590/S1516-35982011000800017.

SCHLEMPER, V. et al. Antispasmodic effects of hydroalcoholic extract of Marrubium vulgare on isolated tissues. Phytomedicine, v.3, n.2, p.211-216, 1996. Available from: <https://doi.org/10.1016/ S0944-7113(96)80038-9>. Accessed: Sept. 01, 2020. doi: 10.1016/ S0944-7113(96)80038-9.

SHIN, H. Y. et al. Anti-inflammatory activity of motherwort (Leonurus sibiricus L.). Immunopharmacology and Immunotoxicology, v.31, n.2, p.209-213, 2009. Available from: $<$ https://doi.org/doi:10.1080/08923970 802135443>. Accessed: Sept. 01, 2020. doi: 10.1080/08923970 802135443.

SILVA, J. H. V. et al. Efeito do extrato de urucum na pigmentação da gema dos ovos. Revista Brasileira de Zootecnia, v.29, n.5, p.1435-1439, 2000. Available from: <http://dx.doi.org/10.1590/ S1516-35982000000500022>. Accessed: Sept. 01, 2020. doi:org/10.1590/S1516-35982000000500022.

SILVA, M. A. D. et al. Óleo essencial de aroeira-vermelha como aditivo na ração de frangos de corte. Ciência Rural, v.41, n.4 p.676-681, 2011. Available from: <http://dx.doi.org/10.1590/ S0103-84782011005000034>. Accessed: Sept. 01, 2020. doi: $10.1590 / \mathrm{S} 0103-84782011005000034$

SITAREK, P. et al. The effect of Leonurus sibiricus plant extracts on stimulating repair and protective activity against oxidative DNA damage in $\mathrm{CHO}$ cells and content of phenolic compounds. Oxidative Medicine and Cellular Longevity, v 2016, art. ID 5738193, p. 1-11, 2016. Available from: <https:// doi.org/10.1155/2016/5738193>. Accessed: sep. 01, 2020. doi: $10.1155 / 2016 / 5738193$

SITAREK, P. et al. Antibacterial, anti-Inflammatory, antioxidant, and antiproliferative properties of essential oils from hairy and normal roots of Leonurus sibiricus L. and their chemical composition. Oxidative Medicine and Cellular Longevity, v.2017, art. ID7384061, p.1-12. 2017. Available from: <https:// doi.org/10.1155/2017/7384061>. Accessed: Sept. 01, 2020. doi: $10.1155 / 2017 / 7384061$

ŠPERŇÁKOVÁ, D. et al. Effects of dietary rosemary extract and $\alpha$-tocopherol on the performance of chickens, meat quality, and lipid oxidation in meat storaged under chilling conditions. Bulletin of the Veterinary Institute in Pulawy, v.51, n.4, p.585-589, 2007. Available from: <http://jvetres.piwet.pulawy.pl/images/stories/ pdf/20074/20 074585590.pdf/>. Accessed: Sept. 01, 2020. ISSN 2450-7393.

TOGHYANI, M. et al. Effect of different litter material on performance and behavior of broiler chickens. Applied Animal Behaviour Science, v.122, n.1, p.48-52, 2010. Available from: $<$ https://doi.org/10.1016/j.applanim.2009.11.008>. Accessed: Aug. 31, 2020. doi: 10.1016/j.applanim.2009.11.008.

VILLANUEVA, J. R. et al. A reassessment of the Marrubium vulgare L. herb's potential role in diabetes mellitus type 2: First results guide the investigation toward new horizons. Medicines, v.4, n.3, p.57, 2017. Available from: <https://doi.org/ 10.3390/ medicines4030057>. Accessed: Aug. 31, 2020. doi: 10.3390/ medicines403.00 57 .

WALLACE, R. J. et al. Dietary plant bioactives for poultry health and productivity. British Poultry Science, v.51, n.4, p.461-87, 2010. Available from: <https://doi.org/10.1080/ 00071668.2010.506908>. Accessed: Aug. 31, 2020. doi: 10.1080/00071668.2010.506908.

WEEL, K. G. C. et al. Antioxidant activity of horehound (Marrubium vulgare L.) grown in Lithuania. Lipid / Fett, v. 101, 395-400, 1999. Available from: <https://doi.org/10.1002/ (SICI)1521-4133(199910)101:10<395::AID-LIPI395>3.0.CO; 2-L $>$. Accessed: Aug. 31, 2020. doi: 10.1002/(SICI)15214133(199910) 101:10<395:: AID-LIPI395>3.0.CO;2-L.

WENK, C. Herbs and botanicals as feed additives in monogastric animals. Asian-Australasian Journal of Animal Science, v.16, n.2, p.282-289, 2003. Available from: <https://doi.org/10.5713/ ajas.2003.282>. Accessed: Aug. 31, 2020 doi: 10.5713/ ajas.2003.282.

WINDISCH, W. et al. Use of phytogenic products as feed additives for swine and poultry. Journal of Animal Science, v.86, n.suppl.14, p.E140-E148, 2008. Available from: <https:// doi.org/10.2527/jas.2007-0459>. Accessed: Aug. 31, 2020. doi: $10.2527 /$ jas.2007-0459

ZARAI, Z. et al. The in-vitro evaluation of antibacterial, antifungal and cytotoxic properties of Marrubium vulgare L. essential oil grown in Tunisia. Lipids and Health Disease, v.10, 161, 2011. Available from: <https://doi.org/10.1186/1476-511X-10-161>. Accessed: Aug. 31, 2020. doi: 10.1186/1476-511X-10-161. 